Vol. 9 (2000): 239-251.

\title{
Seed production characters and germination performance of reed canary grass in Finland
}

\author{
Mia K. Sahramaa \\ Agricultural Research Centre of Finland, Crops and Soil, FIN-31600 Jokioinen, Finland, \\ e-mail:mia.sahramaa@mtt.fi \\ Leena Hömmö \\ Ministry of Agriculture and Forestry, Hallituskatu 3 A, FIN-00023 Government, Finland
}

\begin{abstract}
Production of reed canary grass (Phalaris arundinacea L.) seed in Finland may be of interest in the near future. Seed production characters of cultivars Palaton and Venture were studied between 1995 and 1998 at Jokioinen. Effects of harvest time on seed yield, thousand seed weight and seed germination were evaluated for 'Palaton'. Seed yield varied from 2 to $432 \mathrm{~kg} \mathrm{ha}^{-1}$, being only $100 \mathrm{~kg} \mathrm{ha}^{-1}$ on average. In the years of highest seed yields the optimum harvest time was 15 days after complete anthesis. At that time high seed yield was associated with a low proportion of shattered seeds and high thousand seed weight and good seed germination. In an additional experiment, the effect of storage temperature and storage time on seed germination were investigated for 'Venture'. Storage temperature had no significant influence on final germination, but warmer storage significantly speeded up germination rate as recorded after 7 days of germination. After 7 days the percentage of germinated seeds was also significantly higher for seeds stored for $>10$ months than with seeds stored for $<10$ months. The results indicate that seed production of reed canary grass is possible in Finland, but additional information for optimizing seed production techniques and conditions is needed.
\end{abstract}

Key words: germination, harvesting, northern growing conditions, Phalaris arundinacea L., seed shattering

\section{Introduction}

Reed canary grass is a perennial, cross-pollinating allotetraploid $(n=14)$ species (Ambastha 1956), which is distributed widely across the temperate regions of Europe, Asia and North
America. Because of its adaptability to wide range of habitats and high yielding potential, it is used as a feed for livestock in North-America, Russia and also to a minor extent in Norway and in Sweden (Østrem and Marum 1989, Lindvall 1994). In Finland, reed canary grass is a native species, that was bred for forage in the 
Sahramaa, M.K. \& Hömmö, L. Seed production characters of reed canary grass

1970s, but was abandoned mainly because of its relatively low palatability and high concentration of various alkaloids (Ravantti 1980). NorthAmerican plant breeders have, however, developed forage varieties with low alkaloid concentrations (Sheaffer et al. 1990). Therefore, reed canary grass is a potential alternative forage crop for Finland. More recently the species has become an interesting crop for producing raw material for paper and solid fuel. Stands of reed canary grass are high, dense and they produce biomass of some 6 to 8 t dry matter per hectare depending on soil type and fertilizer use (Pahkala 1997). The species has been shown to be the most promising source of short fibre of the field crops studied in Sweden and Finland during the 1990s (Lindvall 1994, Pahkala 1997). Currently reed canary grass is a new crop in Finland covering some 500 ha. Large-scale cultivation, however, requires domestic seed production.

Seed production of perennial grass species is often problematic under Nordic conditions. Grass species usually have a dual induction requirement for flowering (primary and secondary induction), needing a particular day length and temperature during the previous autumn. The required induction conditions vary among grass species. According to previous studies (Heide 1994a, b), reed canary grass is a short-long-day plant which has a dual photoperiodic induction requirement for flowering: low temperature (3$12^{\circ} \mathrm{C}$ ) and/or short days (under 12 hours) for primary induction, and moderately high temperature and/or long days for secondary induction. In the autumn little primary induction takes place under long days and low temperature conditions in this species, which is probably the main reason for low seed yields reported in Norway (Østrem 1988). Autumn application of gibberellin biosynthesis inhibitor CCC (2-chloroethyltrimethylammonium chloride) in seed production has enhanced primary induction and increased seed yield in Norway (Jonassen 1994, Aamlid et al. 1995).

Seed production of reed canary grass also faces other difficulties that have delayed the adoption of this new crop owing to lack of avail- able seed. As for many grass species, seed ripening is not uniform. The panicle matures unevenly and seeds shatter soon after maturity (Balternsperger and Kalton 1959). Therefore, seed yield is often low with irregular germination. Low seed yielding capacity is often correlated with vigourous vegetative growth. Reed canary grass produces substantial biomass under long day conditions and commercial forage varieties tend to produce a dense stand of weak tillers with low flowering capacity. Reed canary grass also produces an expansive underground rhizome and root system.

The objective of the present study was to evaluate the seed production characters of the common North American commercial forage cultivars, Palaton and Venture under Finnish climatic conditions.

\section{Material and methods}

The present investigation comprised two experiments, one on seed production and another on storage, which were carried out at the Agricultural Research Centre of Finland (MTT) in Jokioinen in southern Finland (latitude $60^{\circ} 49^{\prime} \mathrm{N}$ ) between 1995 and 1998. The reed canary grass cultivars used in these experiments were Palaton and Venture. Seed of 'Palaton' was obtained from Seed Link Inc. (Canada) by the Finnish seed company S.G. Nieminen and seed of 'Venture' from Peterson Seed Company, Minnesota, USA. Seed of Venture was bulked in the field in Jokioinen in 1995 before use in the storage experiment.

\section{Seed production experiment}

'Palaton' was established on an organic soil on 28 June 1994. Experiments were superimposed on it in 1995 (experiment 1) and 1996 (experi- 
Vol. 9 (2000): 239-251.

ment 2). The seed production experiment was conducted during 1995-1998. The experimental design was, in both cases, a completely randomized block with four replicates, treatments being different harvest times. Gross plot size was $2 \mathrm{~m} \times 10 \mathrm{~m}\left(20 \mathrm{~m}^{2}\right)$ and net plot size for harvest $1.5 \mathrm{~m} \times 10 \mathrm{~m}\left(15 \mathrm{~m}^{2}\right)$. Nitrogen fertilizer was applied at $30 \mathrm{~kg} \mathrm{~N}^{-1}$ (trade name Typpirikas$\mathrm{Y} ; \mathrm{N}: \mathrm{P}: \mathrm{K}$ at 20:4:8) in the year of establishment and $40 \mathrm{~kg} \mathrm{~N} \mathrm{ha}^{-1}$ annually in the following years. In the year of establishment a basal application of fertilizer was given at sowing with a Simulta sower (Junkkari, Finland) and in the following years with a pneumatic applicator (Tume P12, Finland) after spring harvest. Seed rate used to establish the field was 1100 viable seeds per $\mathrm{m}^{2}$, which corresponds $11.8 \mathrm{~kg}$ seeds per hectare, a thousand seed weight of $0.9 \mathrm{~g}$ and germination of $85 \%$. Seeds were drilled to a depth of 1-2 cm with the Simulta sower and rows were spaced at $12.5 \mathrm{~cm}$. The field was rolled after sowing. Broad leaved weeds were controlled with Hormoprop on 27 July. In the following years no herbicides were used. Seed was harvested every year between July and September depending on timing of complete anthesis. Above ground biomass was removed each spring before the onset of the new growing season.

Seed was harvested from experiment 1 in 1995, 1996, 1997 and 1998 and from experiment 2 in 1996, 1997 and 1998. Thus, in each year seed yield was harvested at different ages of ley. Seed production experiments ended in 1998, when the stand was four years old. Seed was combine harvested with a Wintersteiger experimental combine harvester (Wintersteiger, Austria) set for a stubble height of ca. $40 \mathrm{~cm}$. In experiment 1 , the harvest was done at five days intervals from 10 to 25 days after complete anthesis and in experiment 2 from 15 to 35 days after complete anthesis. Complete anthesis was determined visually from an experimental plot when $70-80 \%$ of the panicles were pollinated. Seed was dried in a warm-air dryer at $+30^{\circ} \mathrm{C}$ (Koja Ltd., Finland), polished and sifted through a $2.5 \mathrm{~mm}$ sieve. Subsequently seeds were stored in paper bags in plastic containers below $10^{\circ} \mathrm{C}$ for 2 to 5 months before testing the germination.

Thousand seed weight (g) was determined prior to the germination test from two replicate samples for each harvest time. One hundred seeds were placed in a plastic germination pot $(\varnothing 15 \mathrm{~cm})$ on a moist filter paper (Tervakoski, tesorb $0 \%, 130 \mathrm{~g} \mathrm{~m}^{-2}$ ) and transferred to the greenhouse. A special germination method was used whereby water was conducted from a water container into the pot by wool, thus keeping the filter paper moist throughout the germination period. The temperature in the greenhouse was adjusted to $20 / 15^{\circ} \mathrm{C}$ (day/night). Greenhouse lights were on from 800 to 2200 and photon flux density was from $290 \mu \mathrm{mol}$ (cloudy day) to 1010 $\mu$ mol (sunny day). Air humidity in the greenhouse ranged between 50 and $70 \%$. Seeds were defined as germinated, when the radicle was at least $2 \mathrm{~mm}$ long. Germinated seeds were counted and removed at seven day intervals and measurements were completed after four weeks.

\section{Storage experiment}

The stand of 'Venture' was established on an organic soil on 28 June 1993. Seeding rate was 1000 viable seeds $\mathrm{m}^{-2}$, corresponding to 10.1 $\mathrm{kg}$ seeds per hectare with a thousand seed weight of $0.91 \mathrm{~g}$ and germination of $90 \%$. Seeds were drilled to a depth of 1-2 cm with the Simulta sower (Junkkari, Finland) and rows were spaced at $12.5 \mathrm{~cm}$. Nitrogen fertilizer was applied at $40 \mathrm{~kg} \mathrm{~N} \mathrm{ha}^{-1}$ and no herbicides or fungicides were used. Seed was harvested with an ordinary threshing machine (Sampo 600, Rosenlew, Finland) on 31 July 1995, about 25 days after complete anthesis. After harvest seeds were dried in a warm-air dryer $\left(+30^{\circ} \mathrm{C}\right)$ and stored in a fabric sack below $10^{\circ} \mathrm{C}$. Germination tests were started one month after harvest. Seeds were transferred to glass pots, which were closed with a parafilm membrane and aluminium foil. One seed lot was stored at room temperature $\left(+20 \pm 2{ }^{\circ} \mathrm{C}\right)$ and another in cooler conditions $\left(+6 \pm 2{ }^{\circ} \mathrm{C}\right)$. Seeds were germinated 


\section{AGRICULTURAL AND FOOD SCIENCE IN FINLAND}

\section{Sahramaa, M.K. \& Hömmö, L. Seed production characters of reed canary grass}

using the same method described previously. The effect of storage at room temperature and at a cooler temperature was tested 19 times at one months intervals (i.e. until March 1997). Data from one testing time (14) were omitted following a mistake in the procedures. The amount of germinated seed was counted seven times at seven days intervals, i.e. 7, 14, 21, 28, 35,42 and 49 days from the beginning of the germination test. Impact of storage temperature and storage time were studied during a 35 day germination test.

\section{Statistical methods}

The data from the seed production experiment were analysed separately for each year using the PROC MIXED (Littell et al. 1996). Seed yield, thousand seed weight and germination data were analysed using analysis of variance for a randomized complete block design. Effect of harvest time on seed yield, thousand seed weight and germination were examined for each harvest time using the ESTIMATE statement of the PROC MIXED. The normality of the data was examined by using univariate procedures, normal probability plots and scatter diagrams for residual variance.

The data from the storage experiment were analysed using PROC MIXED (Littell et al. 1996). Effects of storage time and storage temperature on the number of germinated seeds were analysed using analysis of variance for a randomized complete block design. Differences in germination associated with storage times and storage temperatures were examined using the ESTIMATE statement of the PROC MIXED. The normality of the data for the traits was studied using univariate procedures, normal probability plots and scatter diagrams for residual variance. Tukey's honestly significant difference (HSD) test $(\mathrm{P}<0.05)$ was also used for the pairwise comparison of means for data from germination at different storage temperatures after 7 to 49 days of the germination test.

\section{Results and discussion}

\section{Seed production experiment}

Both seed production experiments were established in 1994, but seed from experiment 2 was not harvested until 1996. In experiment 1 , the first seed was harvested one year after establishment and seed yield was very low, 50-100 kg ha $^{-1}$. In 1996, two years after establishment, seed yield, germination and thousand seed weight were the highest recorded (Tables 1 and 2). Seed yield was higher in experiment $2(215-367 \mathrm{~kg}$ $\left.\mathrm{ha}^{-1}\right)$ than in experiment $1\left(157-240 \mathrm{~kg} \mathrm{ha}^{-1}\right)$, from which seed had already been harvested a second time. Seed harvest in the first year after establishment seems to have affected negatively the seed yield the following year. Irrespective of the previous harvests, there was a dramatic decline in seed yield in both experiments in 1997 and 1998. Seed yield collapsed from its highest (200-300 kg ha-1) recorded in a two-year old plant stand to only a few kilograms (4-30 $\left.\mathrm{kg} \mathrm{ha}^{-1}\right)$. In concert with a decrease in seed yield, thousand seed weight and germination percentage also decreased drastically (Tables 1 and 2).

Large variations in seed production characters of reed canary grass were recorded. Seed yield varied from 2 to $432 \mathrm{~kg} \mathrm{ha}^{-1}$, germination from 12 to $98 \%$ and thousand seed weight from 0.38 to $1.06 \mathrm{~g}$ depending on year and harvest time. During the period 1995-1998 seed yield of reed canary grass averaged $100 \mathrm{~kg} \mathrm{ha}^{-1}$. In 1995 and 1996 average seed yields were highest (86-304 $\mathrm{kg} \mathrm{ha}^{-1}$ ), but they were relatively low when compared with seed yields harvested from other small-grain forage grasses in Finland like timothy (Phleum pratense L.) (450-750 kg ha-1, thousand seed weight $0.54 \mathrm{~g}$ ), red fescue (Festuca rubra L.) (190-350 kg ha-1, thousand seed weight $1.05 \mathrm{~g}$ ) and meadow grass (Poa pratensis L.) (90-420 kg ha-1, thousand seed weight $0.35 \mathrm{~g}$ ) (Mustonen et al. 1987).

According to results from Norwegian studies (Østrem 1988), hardly any primary induction takes place under long days and low tempera- 
Vol. 9 (2000): 239-251.

ture conditions in these species, which may contribute to the results from this study. In addition to the possible lack of primary induction in autumn, there may be other reasons for the poor seed yield. In the work of Hillestad (1994), reed canary grass was cut in the autumn of the year of establishment. In the following year there was a reduction of $7-11 \%$ in seed yield. In the experiments of Jonassen (1994) the negative effect of autumn cutting on seed yield was even more dramatic. Seed yield of spring-planted reed canary grass cut in September was half that of uncut plots $\left(650 \mathrm{~kg} \mathrm{ha}^{-1}\right)$ when the first seed was harvested the following July. Thus, in seed production, a reed canary grass ley should not be cut the year of establishment to permit build up a reserve of carbohydrates in the root system before growth ceases in the autumn. Heichel et al. (1980) studied effects of seedling age and cold treatment on panicle production of reed canary grass in the glasshouse and growth chamber. They found that even moderate defoliation before onset of primary induction reduced the number of panicles. On contrary, in the sown experiments of Bromus inermis (Aamlid et al.1995) cutting on September produced higher seed yields than earlier cutting. That was probably because more redundant material, in particular elongated tillers, was removed on later cutting. In this study, the effect of harvest time on seed yield of the following year was not clear. In 1995 and 1997 seed was harvested between 14.7-18.8 and harvest time had no effect to the seed yield of the next year. Only in 1996 latest seed harvests were made in the end of August and in early September, and the seed yield of the next year was highest in later harvested plots.

Another possible reason for the poor seed yield of reed canary grass was insect pests. Reed canary grass was regarded as almost free of pests until the first observations of leafhoppers were made in variety trials in Jokioinen in 1995. Insect samples were collected also from the field from the seed production experiments and the number of pests was high especially in 1997 and 1998 (Vasarainen et al. 1999). The most common group of insects on reed canary grass was larvae of leafhoppers (Balclutha punctata F.), feeding on the immature seeds. Larvae of leafhoppers also increased the colonisation of panicles by moulds. Gall midges (genus Mayetiola) cut stems of reed canary grass, but they were less harmful than leafhoppers for seed production. The effect of pests was not thoroughly studied in these experiments.

Environmental conditions from flowering to maturity affect the ability of a crop to retain its seed (Elgersma et al. 1988). The flowering of reed canary grass may be depressed by unfavourable conditions (low temperature, lack of precipitation) (Evans and Ely 1941). Although summer 1998 was rainy and relatively cool in Jokioinen, air temperature and monthly precipitation did not differ from annual means (Table 3 ). However, the total number of full sunshine hours (May-September) was only 861 in 1998, whereas in 1995-1997 it was 1211.

Determination of the optimum harvest time for reed canary grass was difficult. The plant stand typically matures unevenly, both between and within panicles. Mature seed also shatters soon after maturity and hence, seed yield is low with irregular germination. In this experiment harvest time affected seed yield, germination percentage, germination rate and thousand seed weight. In the years of highest seed yields (1995, 1996) early harvest (10 days after complete anthesis) resulted in lower yield, thousand seed weight and germination percentage than later harvests. The amount of unripe seeds in panicles was most likely high at early harvest, and seeds may have been injured when combine harvested. Germination rate was also lower when the seed was harvested 10 days after anthesis, especially in the first year after establishment in 1995 (Fig. 1). At that time the total amount of germinated seed was only $39 \%$ in 28 days, whereas in later harvests it was over $74 \%$.

In the years of highest seed yields (19951996) the optimum harvest time for 'Palaton' was 15 days after complete anthesis i.e., at a temperature sum of approximately $800 \mathrm{dd}$. At this time high seed yield (100-369 $\mathrm{kg} \mathrm{ha}^{-1}$ ) was associated with a low proportion of shattered seeds and 
Sahramaa, M.K. \& Hömmö, L. Seed production characters of reed canary grass


高

容

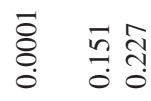

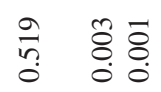

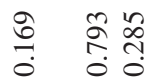

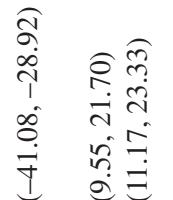

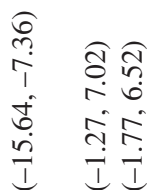

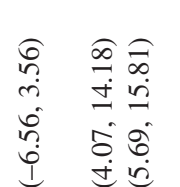

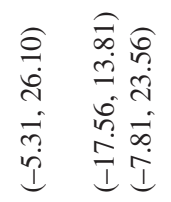

总

鸹

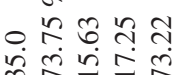

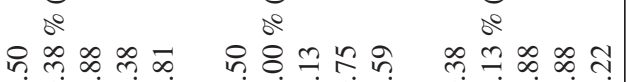

छ్

ह્ळ

造起

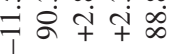

Tト $\stackrel{+}{+} \underset{+}{\infty}$

$\stackrel{+}{+} \underset{1}{+}$

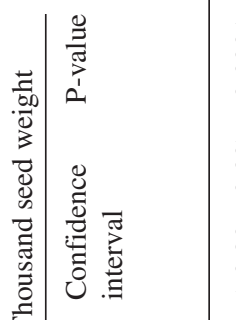

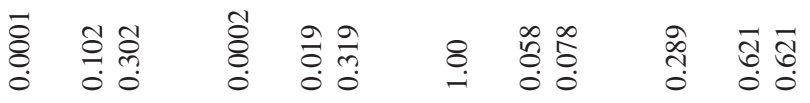

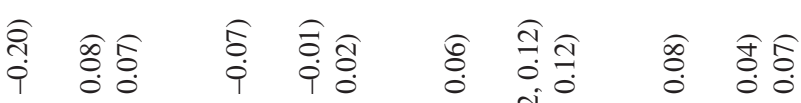



F





胥

苂

危







$\begin{array}{lll}8 & 0 \\ 0 & 0 & 0 \\ 0 & 0 & 0\end{array}$

\begin{tabular}{lll}
$n$ & $\overline{8}$ & $\overline{8}$ \\
\hdashline & 0 & 0 \\
0 & 0
\end{tabular}



离

$\frac{a}{1}$



in

总

से



एٓं



ह్

辛导

m $\stackrel{\infty}{\sim}$











ह్ हี

छ్


(1)



营 离



으능ำ

은ํㄴ

으문ㄱ






Vol. 9 (2000): 239-251.

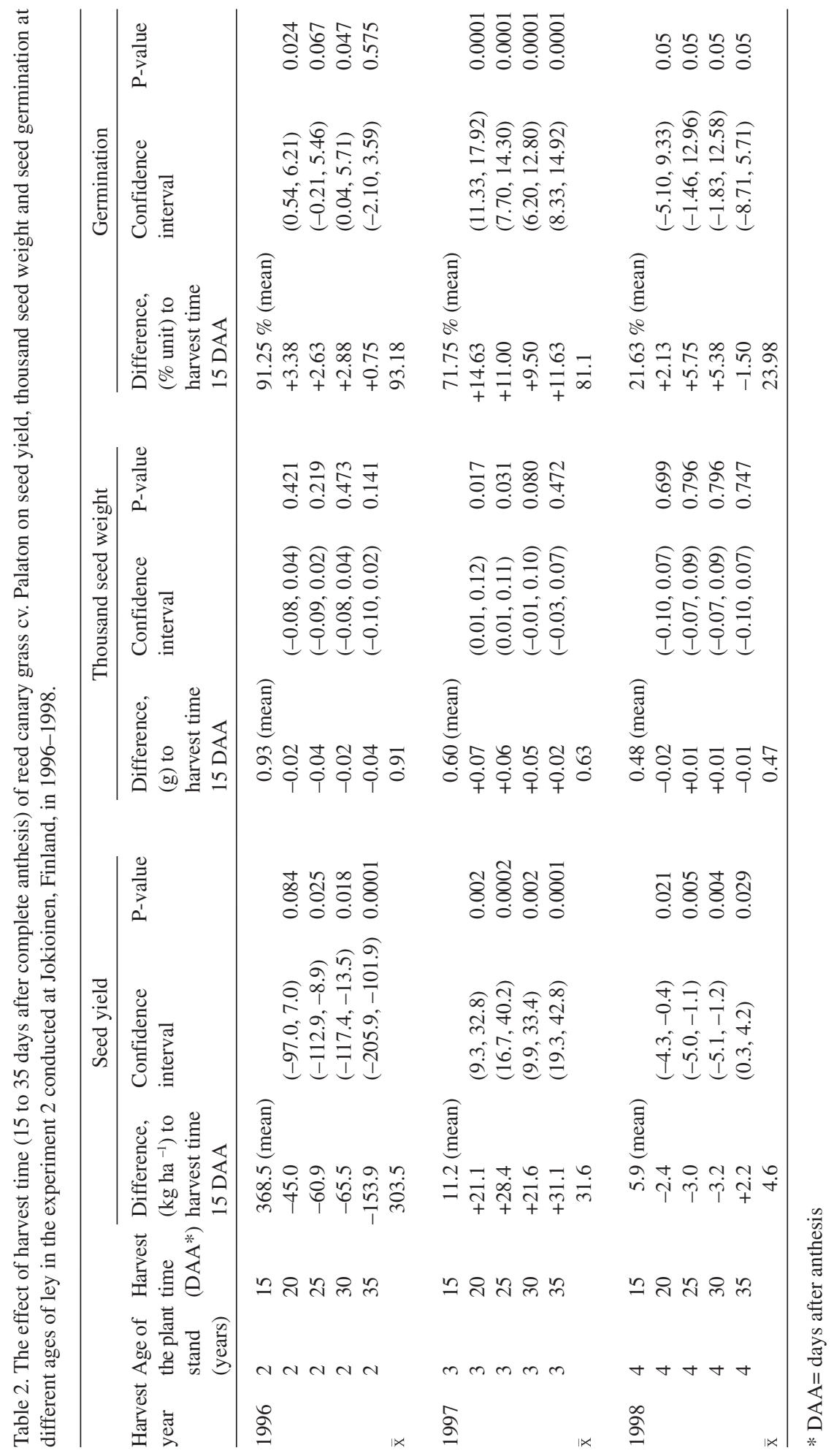




\section{AGRICULTURAL AND FOOD SCIENCE IN FINLAND}

Sahramaa, M.K. \& Hömmö, L. Seed production characters of reed canary grass
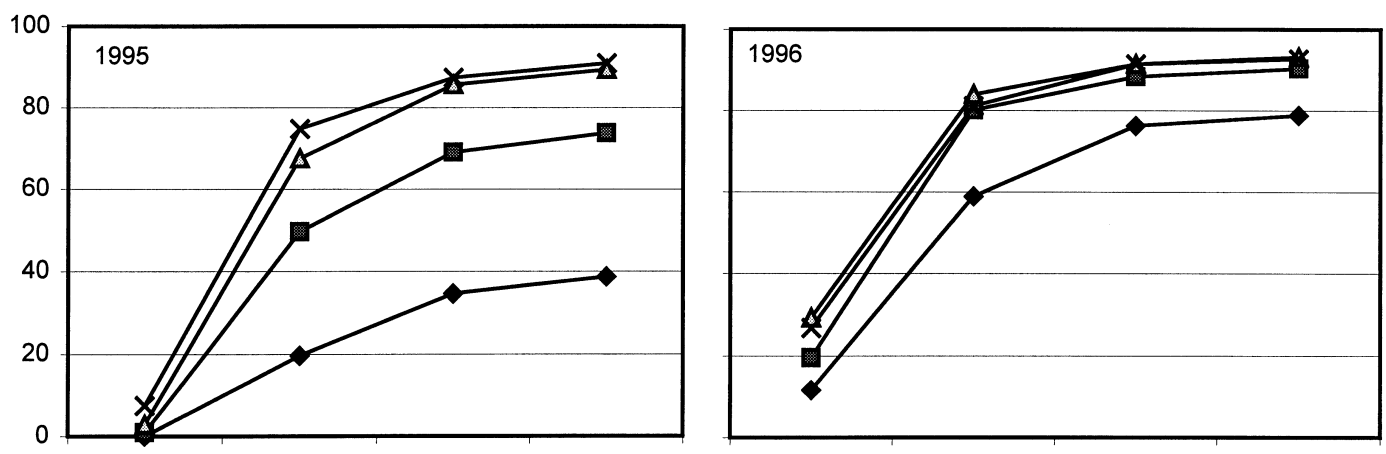

$\%$
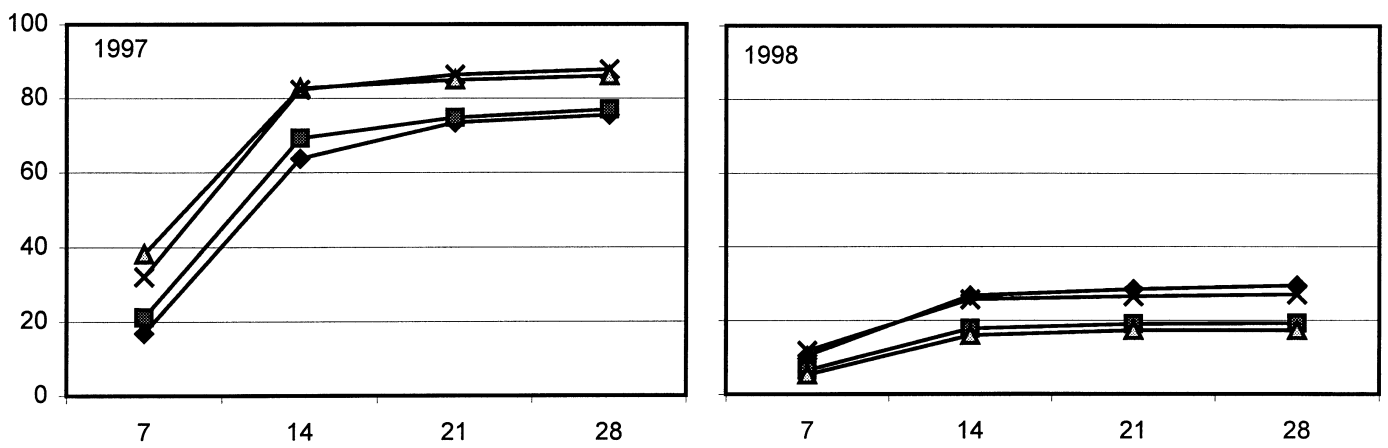

Days of germination

Fig. 1. Germination rate of seeds of reed canary grass cultivar Palaton harvested $10(\bullet), 15(\mathbf{\square}), 20(\mathbf{\Delta})$ and $25(\times)$ days after complete anthesis from an experiment conducted in Jokioinen, Finland in 1995-1998.

Table 3. Deviations from the long-term (1961-1990) average of monthly air temperature $\left({ }^{\circ} \mathrm{C}\right)$ and monthly precipitation (mm) at Jokioinen (May to September), Finland, in 1995-1998.

\begin{tabular}{lrrrrr}
\hline & May & June & July & August & September \\
\hline Mean air temperature $\left({ }^{\circ} \mathrm{C}\right)$ & & & & & \\
$1961-1990$ & 9.4 & 14.3 & 15.8 & 14.2 & 9.4 \\
1995 & -0.7 & +2.4 & -0.5 & +0.9 & +0.9 \\
1996 & -0.6 & -1.2 & -1.9 & +2.8 & -1.1 \\
1997 & -1.7 & +1.8 & +2.0 & +3.6 & +0.6 \\
1998 & -0.2 & -0.6 & -0.6 & -1.2 & +1.1 \\
& & & & & \\
Precipitation (mm) & & & & & \\
$1961-1990$ & 35.3 & 46.6 & 80.2 & 83.1 & 65.1 \\
1995 & +52.0 & +74.0 & -27.0 & -18.1 & -20.5 \\
1996 & +29.3 & +.5 .7 & +55.3 & -69.2 & -45.0 \\
1997 & -19.5 & +54.6 & +60.9 & -39.4 & +13.1 \\
1998 & +30.1 & +52.4 & -9.9 & +0.2 & -36.0 \\
\hline
\end{tabular}




\section{AGRICULTURAL AND FOOD SCIENCE IN FINLAND}

Vol. 9 (2000): 239-251.

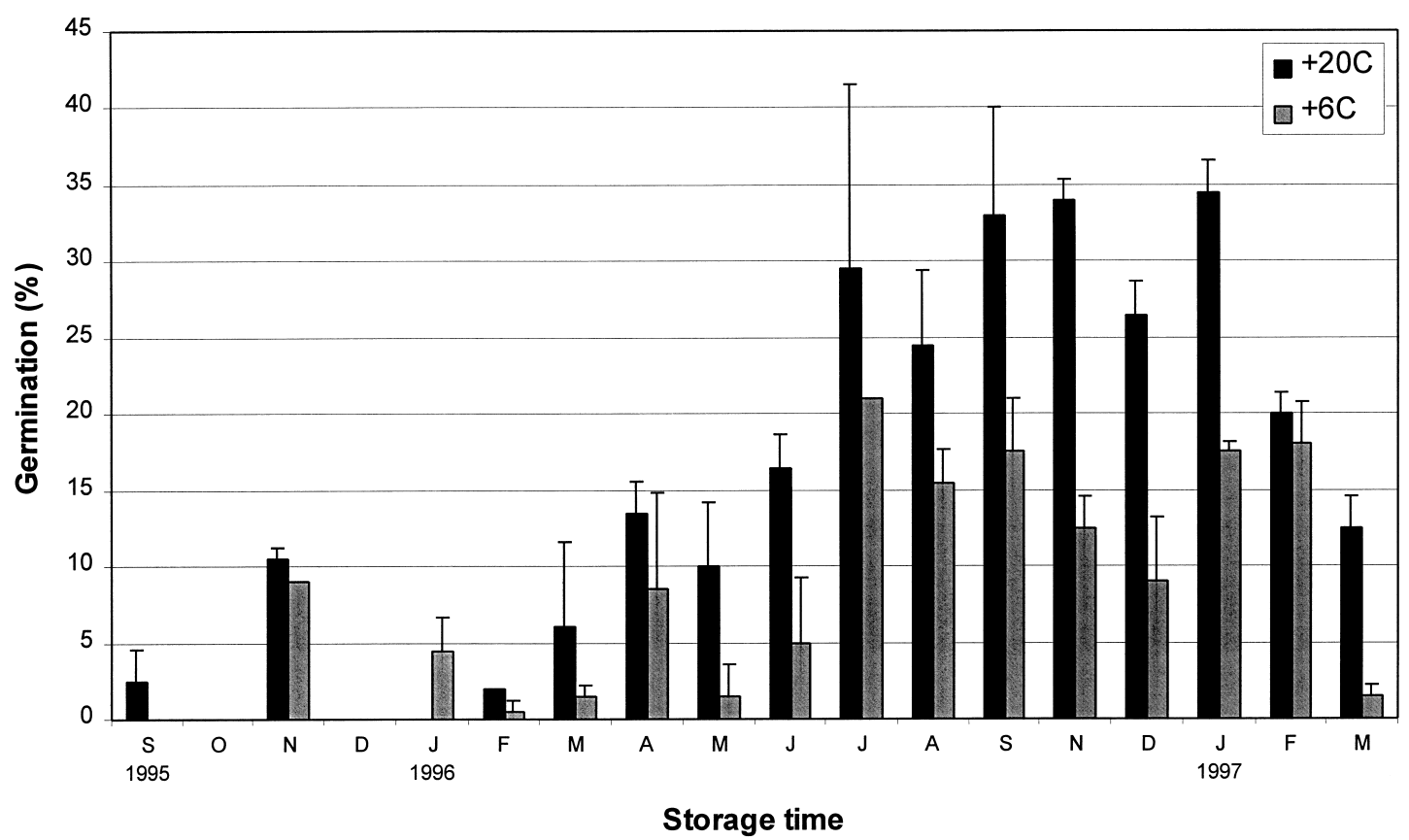

Fig. 2. Mean percentage and standard deviation of germinated seeds of reed canary grass cultivar Venture after seven days of germination test using seed stored at $+20^{\circ} \mathrm{C}$ and $+6^{\circ} \mathrm{C}$ in an experiment conducted between 1995 and 1997 using seed harvested in 1995.

high thousand seed weight $(0.93-1.04 \mathrm{~g})$ and seed germination (74-91\%). In 1997 and 1998 seed yield $\left(2.7-42 \mathrm{~kg} \mathrm{ha}^{-1}\right)$, thousand seed weight $(0.45-0.7 \mathrm{~g})$ and germination $(17-87 \%)$ were low in general and highest seed yields were recorded from later harvests. Optimum time for harvest is a compromise between maximum seed yield, seed losses following shedding, thousand seed weight and germination percentage. The germination of reed canary grass should be at least $75 \%$, and its purity $96 \%$, to fulfil the requirements for certified seed production (Maataloustuottajain Palvelu Oy 1997).

\section{Storage experiment}

The effect of storage temperature $\left(+20^{\circ} \mathrm{C}\right.$ and $+6^{\circ} \mathrm{C}$ ) and storage time (1-19 months) on germination were tested for 'Venture'. During the 19 months testing period, and according to the results of a 35-day germination test, the germination percentage varied from 67 to $100 \%$. Mean germination percent of 'Venture' was relatively high during the testing period being $84 \%$ at room temperature and $86 \%$ at a cooler temperature. Landgraff and Junttila (1979) also found out in their experiments that germination capacity $(80$ $95 \%$ ) of reed canary grass was not altered over a period of one year at room temperature (20$30^{\circ} \mathrm{C}$ ). In the present study there was no significant difference between effects of storage temperatures and no storage temperature $\times$ storage time interaction for total observed germination. The only time when storage temperature significantly affected the amount of germinated seeds was seven days from the beginning of the germination test (Fig. 2): seeds stored at room temperature had a higher mean germination percentage $(15 \%)$ than seed stored at the lower temperature $(8 \%)$ (Table 4$)$. Germination percentage varied from 0 to $38 \%$ when seeds were stored at 
Sahramaa, M.K. \& Hömmö, L. Seed production characters of reed canary grass

Table 4. The effect of storage temperature (room $+20^{\circ} \mathrm{C} /$ cool $+6^{\circ} \mathrm{C}$ ) on the number of germinated seeds of reed canary grass cv. Venture in the storage experiment conducted at Jokioinen, Finland in 1995-1997. The amount of germinated seeds was counted seven times at seven days intervals from the beginning of the germination test. Means with the same letter are not significantly different (Tukey's HSD test, $\mathrm{P}<0.05, \mathrm{n}=36$ ).

\begin{tabular}{lrrr}
\hline Days & Temperature & $\begin{array}{c}\text { Mean number of } \\
\text { germinated seeds }\end{array}$ & $\begin{array}{c}\text { Std } \\
\text { deviation }\end{array}$ \\
\hline 7 & room & $15.31 \mathrm{a}$ & 12.67 \\
& cool & $7.94 \mathrm{~b}$ & 7.49 \\
14 & room & $61.81 \mathrm{a}$ & 24.01 \\
& cool & $56.72 \mathrm{a}$ & 22.20 \\
21 & room & $71.11 \mathrm{a}$ & 19.55 \\
& cool & $71.39 \mathrm{a}$ & 19.93 \\
28 & room & $78.94 \mathrm{a}$ & 14.08 \\
& cool & $80.06 \mathrm{a}$ & 16.60 \\
35 & room & $84.25 \mathrm{a}$ & 8.60 \\
& cool & $85.92 \mathrm{a}$ & 8.14 \\
42 & room & $85.75 \mathrm{a}$ & 7.96 \\
& cool & $87.03 \mathrm{a}$ & 7.50 \\
49 & room & $86.53 \mathrm{a}$ & 7.55 \\
& cool & $87.92 \mathrm{a}$ & 7.19 \\
\hline
\end{tabular}

room temperature and from 0 to $21 \%$ in the cool. The effect of temperature on seed germination was also tested in the experiments of Vose (1962). Contrary to our results, cold-treated seeds $\left(3^{\circ} \mathrm{C}, 14\right.$ days) exhibited enhanced germination for the first 8 days. At the end there was no significant difference in total germination between the cold-treated seeds and the control.

Storage temperature $\mathrm{x}$ storage time interaction was significant for germination only over the first 7 days of the germination test. Thus, the effect of storage time on germination was calculated separately for both storage temperatures. As a general rule the percentage of germinated seeds was significantly higher with seeds stored a longer time (10-19 months) than with seeds stored a shorter time ( $<10$ months) at both storage temperatures (Fig. 2). The difference in germination was even higher at room temperature. In longer storage the amount of germinated seeds was $26 \%$ at room temperature and $13 \%$ at the cooler temperature. Germination of seeds stored a shorter time was $5 \%$ at room temperature and $3 \%$ in the cool.

After 35 days the difference in germination attributable to storage times was modest, although significant. The results from storage tests made in November 1995 (96\%), November 1996 (94\%) and February 1997 (94\%) were significantly higher than those recorded in March 1996 (77\%) and May 1996 (75\%). In this 19-month germination test seeds of 'Venture' retained a $>75 \%$ germination. Some fluctuation was recorded in total germination percentage during the testing time: germination percentage was higher immediately after harvest and it declined over the winter and summer being high again in the subsequent winter (Fig. 3). A similar but more marked annual periodicity in germination was reported for a hexaploid hybrid of Phalaris arundinacea $\mathrm{x}$ Phalaris tuberosa by Vose (1962).

Seed dormancy is usually strong in wild $P h a$ laris populations, but varieties have normally lost much of their seed dormancy, probably during natural selection over successive generations of seed multiplication (Berg 1992). According to Østrem, (1988) seed dormancy was automatically reduced as a consequence of seed propagation and there were no differences between bred and non-bred populations. In this study the effect of seed dormancy was not clear. Although the total amount of germinated seeds was relatively high following each storage duration, the germination rate was lower for seeds stored for a shorter period. After August 1996 (test month 12) $70 \%$ of seeds germinated in 14 to 21 days, whereas previously it took about 28 days to achieve the same rate.

\section{Summary}

In conclusion, the seed production capacity of 'Palaton' remained moderate only two years after establishment, and seed yield was highest when harvest was delayed until after the first year 


\section{AGRICULTURAL AND FOOD SCIENCE IN FINLAND}

Vol. 9 (2000): 239-251.

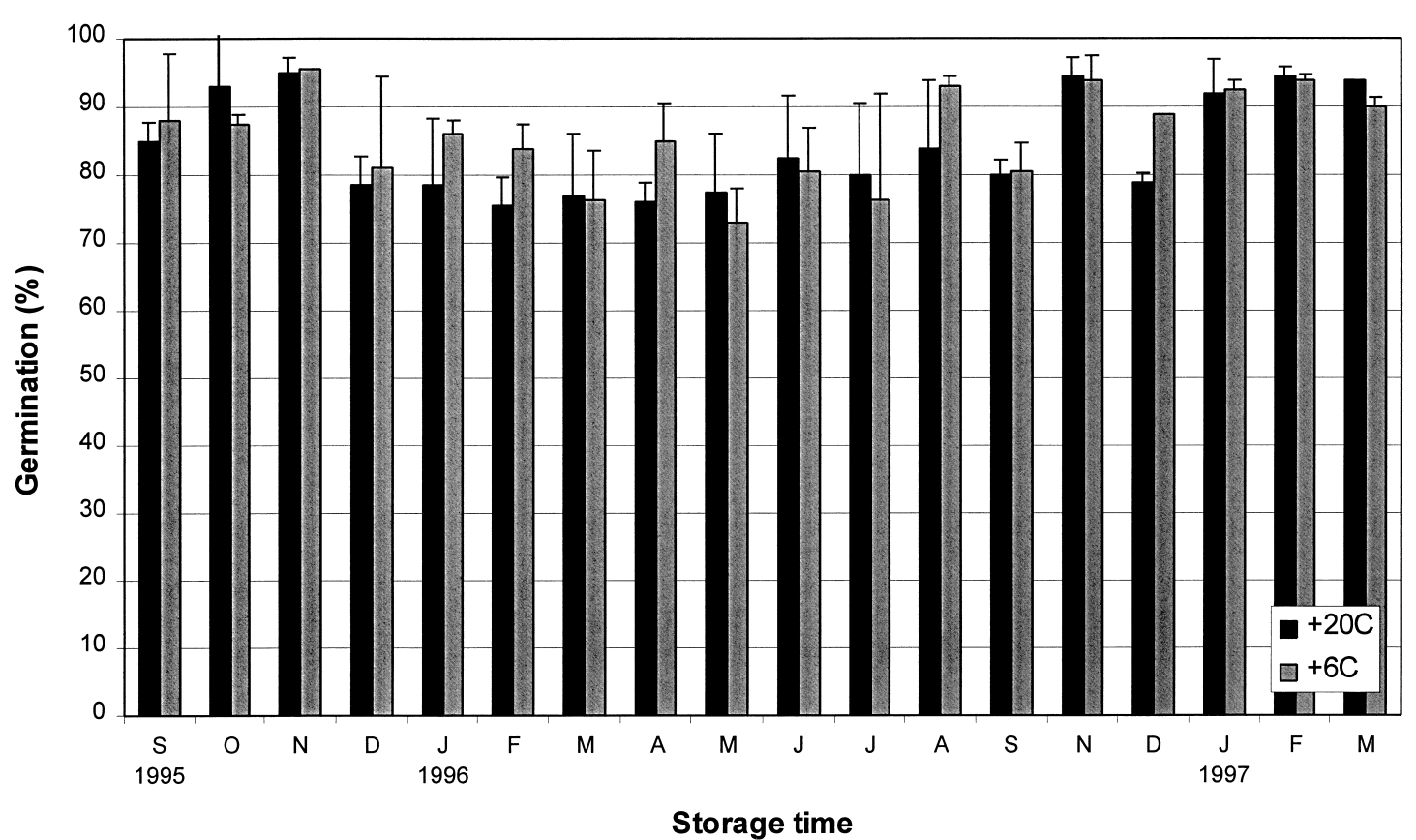

Fig. 3. Mean percentage and standard deviation of germinated seeds of reed canary grass cultivar Venture after 35 days of a germination test using seed stored at $+20^{\circ} \mathrm{C}$ and $+6^{\circ} \mathrm{C}$ in an experiment conducted between 1995 and 1997 using seed harvested in 1995.

of establishment. Variation in seed production characters was high among different years and seed yield decreased from hundreds of kilograms to only a few dozen kilograms. In the years of highest seed yields (1995-1996) the optimum harvest time for 'Palaton' was 15 days after complete anthesis. At this time high seed yield was associated with a low proportion of shattered seeds and high thousand seed weight and seed germination. Germination ability of 'Venture' remained relatively high during the 19 month testing period and storage temperature had an effect only on early germination rate. The maximum number of germinated seeds was achieved in 35 days.

All seed of reed canary grass is imported into
Finland from the USA, which will also be the case in the future for both non-forage and forage production, until domestic cultivars are released and problems related to their seed production are understood better. Our study indicate that seed production of reed canary grass is possible in Finland, but additional information for optimizing seed production techniques and conditions is needed.

Acknowledgements. We are grateful to Ms. Helena Ihamäki and Ms. Aino Lahti for their skillful technical assistance. Professor Pirjo Peltonen-Sainio is warmly thanked for her valuable comments on the manuscript. This research was supported by the Ministry of Agriculture and Forestry in Finland and by the Scientific Foundation of the Finnish Association of Academic Agronomists. 


\title{
AGRICULTURAL AND FOOD SCIENCE IN FINLAND
}

\author{
Sahramaa, M.K. \& Hömmö, L. Seed production characters of reed canary grass
}

\section{References}

Aamlid, T.S., Skuterud, R., Heide, O.M. \& Torskenæs, E. 1995. Autumn application of chlormequat chloride (CCC) in seed production of Bromus inermis. Norwegian Journal of Agricultural Sciences 9: 271-279.

Ambastha, H.N.S. 1956. Cytological investigations in Phalaris. Genetica 28: 64-98.

Baltensperger, A.A. \& Kalton, R.R. 1959. Variability in reed canarygrass, Phalaris arundinacea L. II Seed shattering. Agronomy Journal 51: 37-38.

Berg, T. 1992. Seed dormancy in local populations of Phalaris arundinacea L. Acta Agriculturae Scandinavica 32: 405-409.

Elgersma, A., Leeuwangh, J.E. \& Wilms, H.J. 1988. Abscission and seed shattering in perennial ryegrass (Lolium perenne L.). Euphytica 8: 51-57.

Evans, M.W. \& Ely, J.E. 1941. Growth habits of reed canary grass. Journal of the American Society of Agronomy 33: 1018-1027.

Heichel, G.H., Hovin, A.W. \& Henjum, K.I. 1980. Seedling age and cold treatment effects on induction of panicle production in reed canarygrass. Crop Science 20: $683-687$.

Heide, O.M. 1994a. Control of flowering in Phalaris arundinacea. Norwegian Journal of Agricultural Sciences 8: 259-276.

- 1994b. Control of flowering and reproduction in temperate grasses. New Phytologist 128: 347-362.

Hillestad, R.1994. Seed production of reed canarygrass (Phalaris arundinacea L.) in Norway. NJF-seminarium nr. 241 Fröproduktion, Jokioinen, Finland. p. 113116.

Jonassen, G.H. 1994. Autumn treatment in reed canarygrass (Phalaris arundinacea L.) and smooth bromegrass (Bromus inermis L.) for seed production. NJFseminarium nr. 241 Fröproduktion, Jokioinen, Finland. p. 123-133.

Landgraff, A. \& Junttila, O. 1979. Germination and dor- mancy of reed canary-grass seeds (Phalaris arundinacea). Physiologia Plantarum 45: 96-102.

Lindvall, E. 1994. Reed canary grass in Sweden - plant breeding and practical experience. NJF-seminarium nr. 241 Fröproduktion, Jokioinen, Finland. p. 107111.

Littell, R.C., Milliken, G.A., Stroup, W.W. \& Wolfinger, R.D. 1996. SAS System for Mixed Models. SAS Institute, Inc., NC, USA.

Maataloustuottajain Palvelu Oy 1997. Kylvösiemen, kasvinviljelijän ammattilehti. Nro 1/97: 22-27.

Mustonen, L., Pulli, S., Rantanen, O. \& Mattila, L. 1987. Virallisten lajikekokeiden tuloksia 1979-1986. Maatalouden tutkimuskeskus, Tiedote 7: 138-161.

Østrem, L. 1988. Studies on genetic variation in reed canarygrass, Phalaris arundinacea L. III. Seed yield and seed yield components. Hereditas 108: 159-168.

- \& Marum, P. 1989. Strandrøyr - avling, kvalitet og alkaloidinnhald. Norsk Landbruksforskning 3: 217223. (in Norwegian with English summary).

Pahkala, K. 1997. Sellua peltokasveista. Peltokasvien soveltuvuus sellun raaka-aineeksi. Lisensiaatintutkimus. Helsingin yliopisto. Julkaisu No: 47. 121 p.

Ravantti, S. 1980. Ruokohelpi - millainen heinäkasvi. Koetoiminta ja käytäntö 5.2.1980.

Sheaffer, C.C., Marten, G.C., Rabas, D.L., Martin, N.P. \& Miller, D.W. 1990. Reed canarygrass. Station Bulletin 595. Minnesota Agricultural Experiment Station. University of Minnesota. $8 \mathrm{p}$.

Vasarainen, A., Hannukkala, A. \& Grahn, J. 1999. Pests and diseases of reed canary grass, Phalaris arundinacea (L.). Proceedings of the COST 814 workshop, Crop development for the cool and wet regions of Europe. Turku, Finland (in press).

Vose, P.B. 1962. Delayed germination in reed canarygrass Phalaris arundinacea L. Annals of Botany 26: 197-206. 
Vol. 9 (2000): 239-251.

\title{
SELOSTUS
}

\section{Ruokohelven siementuotanto-ominaisuudet ja itäryys Suomessa}

\author{
Mia K. Sahramaa ja Leena Hömmö \\ Maatalouden tutkimuskeskus ja Maa- ja metsätalousministeriö
}

Ruokohelpi (Phalaris arundinacea L.) on osoittautunut potentiaaliseksi uudeksi viljelykasviksi kuidun, energian ja rehuntuotannossa. Suomessa ei ole kotimaisia ruokohelpilajikkeita, mutta siementuotanto ulkomaisista rehulajikkeista saattaa tulla ajankohtaiseksi ruokohelven viljelyn yleistyessä. Amerikkalaisten Palaton ja Venture -rehulajikkeiden siementuotantoominaisuuksia tutkittiin Maatalouden tutkimuskeskuksessa Jokioisilla kahdessa kokeessa vuosina 1995-1998.

Siementuotantokokeessa tutkittiin korjuuajankohdan vaikutusta Palaton-lajikkeen siemensatoon, tuhannen siemenen painoon ja itävyyteen. Palatonin keskimääräinen siemensato oli ainoastaan $100 \mathrm{~kg} \mathrm{ha}^{-1}$ ja siementuotanto-ominaisuudet vaihtelivat paljon. Siemensato vaihteli välillä 2-432 kg ha-1, tuhannen siemenen paino 0,38-1,06 ja itävyys $12-98 \%$ vuoden ja korjuuajan mukaan. Ensimmäisen ja toisen vuoden kasvustot tuottivat parhaan siemensadon (100-369 $\mathrm{kg} \mathrm{ha}^{-1}$ ), ja tuolloin myös tuhannen sieme- nen paino ja itävyys olivat korkeat. Parhaina satovuosina Palatonin optimaalinen korjuuajankohta oli 15 päivää kukinnan päättymisestä. Kolmannen ja neljännen vuoden kasvustoissa siemensato putosi muutamaan kymmeneen kiloon.

Varastointikokeessa selvitettiin varastointilämpötilan $\left(+20^{\circ} \mathrm{C} \mathrm{ja}+6^{\circ} \mathrm{C}\right)$ ja ajan $(1-19 \mathrm{kk})$ vaikutusta Venture-lajikkeen siementen itävyyteen. Itäneiden siementen määrä laskettiin 7 päivän välein ja 35 päivän kuluessa itäneiden siementen määrän katsottiin olevan maksimaalinen. Varastointilämpötila ja -aika vaikuttivat itäneiden siementen määrään ainoastaan 7 päivää itämistestin aloittamisesta. Lämpimässä varastoitujen siementen itävyys oli korkeampi kuin viileässä varastoitujen, ja yli 10 kuukautta varastoitujen siementen itävyys oli korkeampi kuin alle 10 kuukautta varastoitujen. Tutkimuksen perusteella ruokohelven siementuotanto on Suomessa mahdollista, mutta siementuotannon tekniikasta tarvitaan lisää tietoa. 